\title{
Assessment of chromium, nickel, cobalt and zinc in edible flesh of two tilapia fish species found in Bodo River, Rivers State, Nigeria
}

\author{
*11OWHONDA, NK; ${ }^{2}$ OGALI, RE; ${ }^{3}$ OFODILE, SE
}

*Department of Pure and Industrial Chemistry, University of Port Harcourt, Nigeria

Email Address: kingsleyndubuisiowhonda@gmail.com

\begin{abstract}
Oil exploration, exploitation, oil well fires and pipe-line vandalism are often reported to lead to high levels of pollution of the environment affecting water, land and air. As a result, the safety of specific fish species for human consumption is constantly in doubt and needs assessment. Guinean tilapia (Tilapia guineensis) and Blackchin tilapia (Sarotherondon melanotheron) are two of the highly consumed fish species in Bodo River. The level of chromium, nickel, cobalt and zinc in the flesh of Tilapia guineensis and Sarotherondon melanotheron found in Bodo River were studied using X-ray fluorescence (XRF). The amount of chromium found in the two fish species ranged between $10.3-10.5 \mathrm{mg} / \mathrm{kg}$, nickel $8.7-10.2 \mathrm{mg} / \mathrm{kg}$, cobalt $3.0-4 \mathrm{mg} / \mathrm{kg}$ and zinc $71.2-74.5 \mathrm{mg} / \mathrm{kg}$. The levels of $\mathrm{Cr}, \mathrm{Ni}, \mathrm{Co}$ and $\mathrm{Zn}$ found in these two species of fish were compared to WHO maximum permissible levels of fish for consumption. The results showed that, fish from the study area contain amount of these metals investigated. This result will serve as a baseline for Food Agencies in Nigeria to certify safety of fishes from various rivers before they are sold for consumption to the public is hereby highlighted. () JASEM http://dx.doi.org/10.4314/jasem.v20i3.9
\end{abstract}

Keywords:X-ray fluorescence, Chromium, nickel, cobalt, zinc, Guinean tilapia (Tilapia guineensis), Blackchin tilapia (Sarotherodon melanotheron), Bodo River

Although fish is a major source of protein (Rasheed, 2001), it is also a major source of heavy metals in food (Siverperumalet al., 2007). Furthermore, fish species are used as bio-indicators of heavy metals (Svobodovaet al., 2004) because heavy metal concentration depicts both the present and the past pollution load of an environment (Raveraet al., 2003). Therefore, the safety of fish species for human consumption needs to be constantly studied especially, in areas already known to be polluted.

In trace amounts many elements are useful to the human body but in large amounts they cannot be excreted and thus, bio-accumulate in the body interfering with enzyme activities thus, hindering many body functions (Ongwuegbu and Ijioma, 2003). On the other hand, no amount of some particular element is considered safe. It is importance to constantly study the amount of elements in fishes found in various water bodies to check if they conform to tolerable limits established by various health agencies including European Medicines Agency (EMEA) and WHO especially, in polluted areas. This is very important if one notes that people depend on fish as a major source of protein but unfortunately, fishes accumulate some dangerous elements from the surrounding water to an amount hundreds or even thousands of times higher than the surrounding water (Osman et al., 2007).
Two of the major fish species from Bodo River commonly consumed are Guinean tilapia (Tilapia guineensis) and Blackchin tilapia (Sarotherodon melanotheron). Due to several years of oil exploration and exploitation in Ogoni land, oil well fires and pipe-line vandalism there are several reports stating how badly damaged the water, air and land of the entire Ogoni land is. In recent times, the Federal Government of Nigeria invited the United Nations Environment Programme (UNEP) to independently study Ogoni Environment and make recommendations. The summary of that report is presented in UNEP Job number DEP/1337/GE. The summary of the report is that Ogoni environment is heavily polluted and needs cleaning. However, few studies are available on the safety of consuming specific fish species. Some examples of this study include those by Jumbo et al., (2015) and Kpobari et al., (2013). This study assessed the amount of chromium, nickel, cobalt and zinc in two fish species found in Bodo River and highlights the need for food agencies to monitor fish species from anywhere in Nigeria before they are sold to the public for consumption.

\section{MATERIALS AND METHOD}

Study Area: Bodo community is a part of Ogoni land in Gokana Local Government area of Rivers State. 
Ogoni land has had several incidents of oil spill and oil well fires leading to serious environmental pollution. According to Kpobariet al., (2013) Ogoni land covers $1,000 \mathrm{~km}^{2}$ in the South-East of the Niger
Delta basin (See figure 1) with a population of 832,000 consisting mainly of Ogoni people. The arrow in figure 1 shows the location of Bodo City.

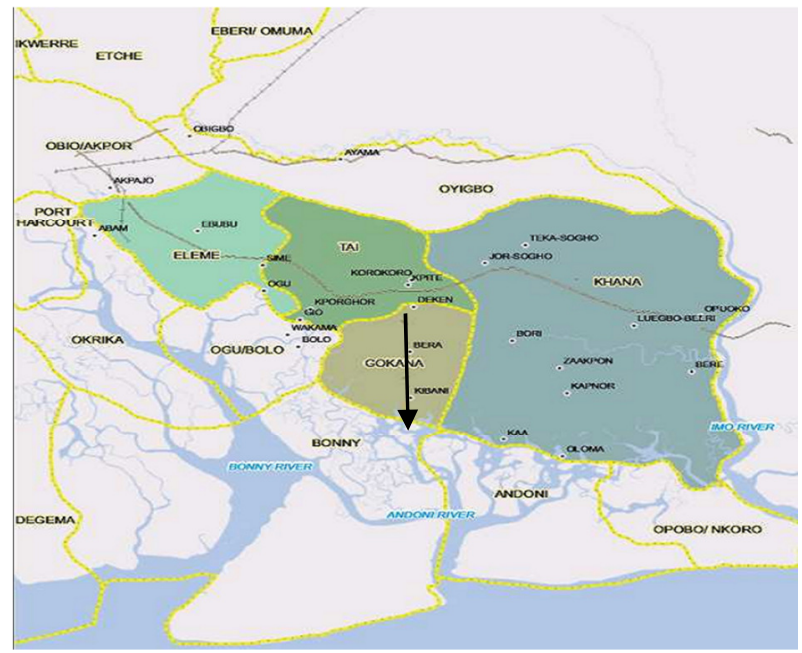

Fig 1: Map of Ogoni land.

Reagents:Analytical grade reagents of high purity were used in the analyses of samples.

Sampling and Sample preparation: The fresh samples of Tilapia guineensis and Sarotherdon melanotheron were collected from Bodo River (See figures 3 and 4). This river is popularly known by the dwellers as "Numuu tekuru". Identity of the fish species was confirmed at the Nigerian Institute for

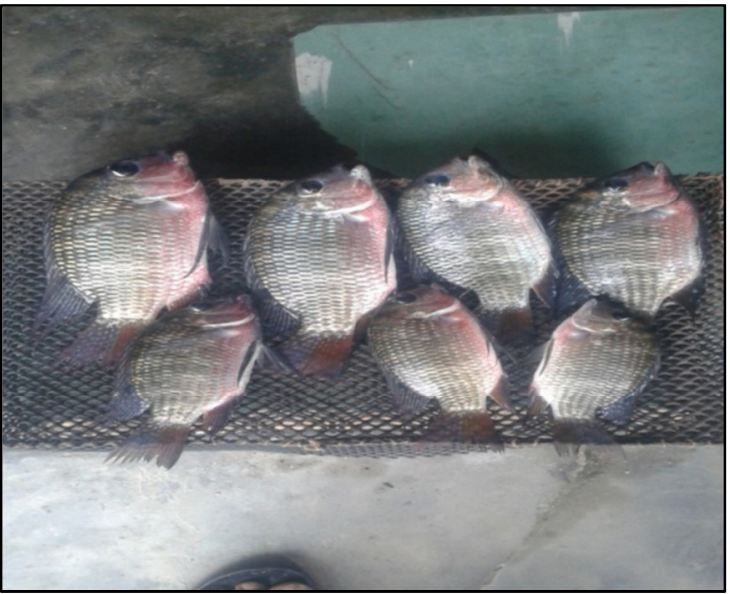

Fig 2:Tilapia guineensis

Sample Analysis and Quality Control: The sample analysis with X-ray fluorescence was carried out at Fugro Nigeria Limited, Port Harcourt. The amount of chromium, cobalt, nickel, cobalt and zinc were determined using X-ray fluorescence spectrometer in accordance with USEPA 6200. Fish samples were oven dried at $110^{\circ} \mathrm{C}$ for twenty hours. With the
Oceanography and Marine Research fish farm, Buguma. Some table size of each fish species were collected, cleaned, wrapped in aluminum foil and put into ice. The entire content was put in a black polyethylene bag and carried in a cooler for analyses.

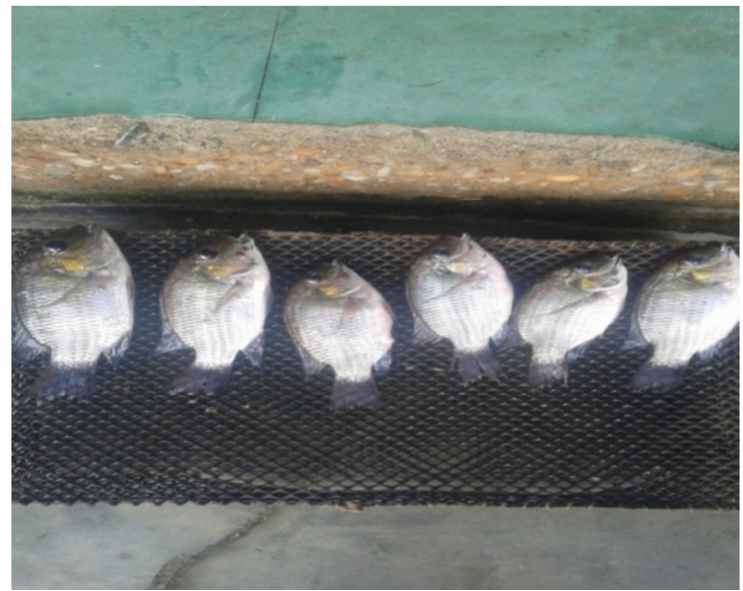

Fig 3:Sarotherodonmelanotheron

unwanted material like bones of fish etc. removed, the fleshy part of the sample was reduced to less than $2 \mu \mathrm{m}$ diameter by crushing. Crushed samples were further pulverized (i.e. crushed until it becomes powder). They were then processed into pressed pellets, transferred to clean prolene foil and then into a sample vial, labelled, arranged in the sample tray 
and finally transferred to the sample compartment of the X-ray fluorescence equipment (SpectroX-LabPro) and then screened for their elemental composition. The concentration of each element was obtained via a previously stored calibration with certified reference materials. Results were calculated automatically as the necessary sample details were computed in the software.

The following information was provided by Fugro for the XRF analysis:

1. XRF excitation source - X-ray tube (synchrotron)
2. Matrix effect was corrected by: grinding grain size to $25 \mu \mathrm{m}$, applying same standard used for calibration to run the sample, using mathematical model Turbo Quant (Lucas tooth) for calibration 3. The sample was analyzed twice to check reproducibility.

4. The mean, standard deviation and mean errors were calculated automatically by the software.

5. The five filters used for the analysis were as follows: Bragg crystal (HOPG), Compton/secondary (Molybdenum), Barkla Scatter (aluminum), Compton/secondary (palladium) and secondary target (K) (cobalt).

\section{RESULTS AND DISCUSSION}

Table 1 shows the amount of the chromium, nickel, cobalt and zinc found in the two fish species while figure 1 compares the various the various amounts in the two fish species.

\begin{tabular}{llccc}
\hline Fish Specie & $\begin{array}{l}\text { Chromium } \\
(\mathbf{m g} / \mathbf{k g})\end{array}$ & $\begin{array}{c}\text { Nickel } \\
(\mathbf{m g} / \mathbf{k g})\end{array}$ & $\begin{array}{c}\text { Cobalt } \\
(\mathbf{m g} / \mathbf{k g})\end{array}$ & $\begin{array}{c}\text { Zinc } \\
(\mathbf{m g} / \mathbf{k g})\end{array}$ \\
\hline Tilapia guineensis & 10.5 & 10.2 & 3.0 & 74.5 \\
Sarotherodonmelanotheron & 10.3 & 8.7 & 4.0 & 71.2 \\
\hline
\end{tabular}

Figure 1: Amount $(\mathrm{mg} / \mathrm{kg})$ of chromium, nickel and cobalt and zinc in Tilapia guineensis and Sarotherodon melanotheron found in Bodo River.

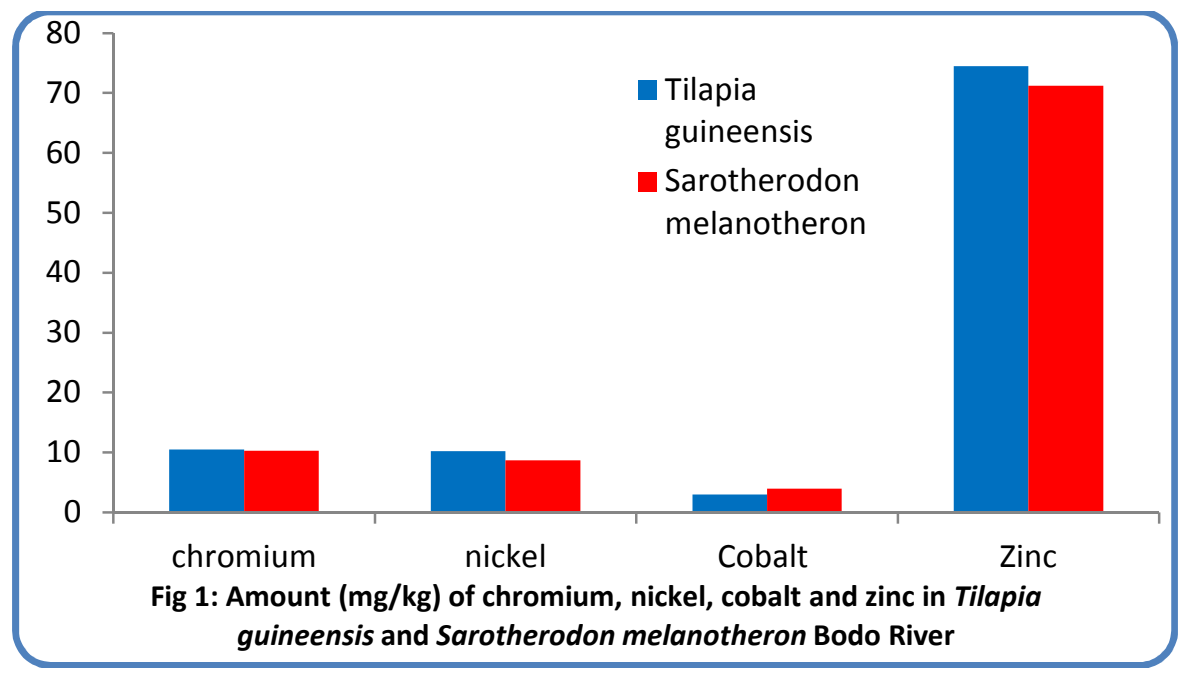

Chromium: The amount of chromium in Tilapia guineensis found in Bodo River ranged between 10.3$10.5 \mathrm{mg} / \mathrm{kg}$. Environmental Protection Agency (1984) has put the amount of chromium in a typical North

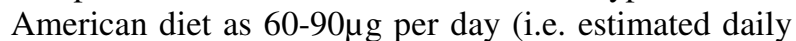
intake). While WHO (2000) says the general range of estimated daily intake (EDI) for chromium in a North

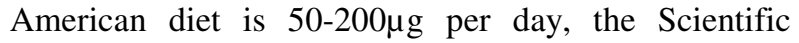
Committee on Food (SCF, 1993) does not specify any daily requirement for chromium since data available on essentiality and metabolism of chromium is so sparse (SCF, 1993). The UK Committee on Medical Aspects of Food Policy (COMA, 1991) calculated a theoretical requirement for adults from balance studies of $23 \mu \mathrm{g} /$ day by using regression equations and concluded that a safe an adequate level lies above $25 \mu \mathrm{g}$ for adults and between $0.1 \mu \mathrm{g} / \mathrm{kg}$ body weight per day and $1.0 \mu \mathrm{g} / \mathrm{kg}$ per body weight per day for children and adolescents respectively. WHO (1996) stated that the average minimum daily requirement of chromium per person is $33 \mu \mathrm{g}$. Kaufaman (1970), Langard and Norseth (1986) and Langard (1983) all reported that consumption of $10-20 \mathrm{mg} / \mathrm{kg}$ of body weight per day of chromium is toxic. 
The reports of Kaufaman (1970), Langard and Norseth (1986) and Langard (1983) suggests that consuming as much as $10 \mathrm{mg} / \mathrm{kg}$ body weight per day of chromium is toxic. Although the lowest amount of chromium that can lead to the toxic effect of chromium is not clearly stated, their finding means that an adult weighing $60 \mathrm{~kg}$ that consumes $600-1,200 \mathrm{mg}$ of chromium per day will suffer from its toxic effects. From table 1 the amount of chromium in $1 \mathrm{~kg}$ of Sarotherodon melanotheron and Tilapia guieensis from Bodo River is $10.3 \mathrm{mg}$ and 10.5 respectively. Since the lowest amount of chromium that can lead to its toxic effect is not clearly defined it is very difficult to draw a conclusion on the safety of the amount of these fish species consumed per day in terms of chromium. Therefore, moderation in the amount of these fish species that are consumed per day is required.

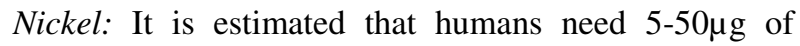
nickel per day and that $4.2 \mu \mathrm{g}$ of nickel per kilogram body weight per day come from food (European Medicines Agency (EMEA, 2007). Racchelle (2008) gives an upper limit of $1 \mathrm{mg}$ of nickel per day for adults from all sources. The amount of nickel in $1 \mathrm{~kg}$ of Tilapia guineensis and Sarotherodon melanotheron found in Bodo River is $10.2 \mathrm{mg}$ and $8.7 \mathrm{mg}$ respectively. The amount of nickel recommended by Racchelle (2008) is equivalent to $98 \mathrm{~g}$ and $115 \mathrm{~g}$ of Tilapia guineensis and Sarotherodon melanotheron respectively. Since the weight of a single table size of both fish species ranges between $54-150 \mathrm{~g}$, it means that consuming as much as two table size of both fish species from Bodo River may not be safe. The people of Bodo City depend mainly on fish as a major source of protein. Therefore, the chances of consuming two or more of any of these two fish species in single day are highly likely. Thus, the dangers of chromium toxicity through the consumption of both fish species found in Bodo River are highlighted.

Cobalt: The largest source of exposure to cobalt is food (WHO, 2006). Cobalt has effect on reproduction and animal development. It is estimated that the daily intake from food alone is $5-40 \mu \mathrm{g}$ and that those with iron deficiency have increased absorption of cobalt (WHO, 2006). As an essential component of vitamin B12 it is found in every tissue. The total amount of cobalt in the human body is $1.1-1.5 \mathrm{mg}$ but with $0.11 \mathrm{mg}$ in the liver alone (WHO, 2006). WHO (2006) reported that humans that ingested $150 \mathrm{mg}$ of cobalt per day for 22 days experienced polycythaemia (i.e. abnormal increase in haemoglobin concentration) while those that consumed large quantities of beer that contained cobalt sulphate suffered from cardiomyopathy. WHO (2006) reported that cobalt exposure of $0.04-0.14 \mathrm{mg} / \mathrm{day} / \mathrm{kg}$ body weight for several years leads to death. This implies that an adult of $60 \mathrm{~kg}$ that consumes $2.4-8.4 \mathrm{mg}$ of cobalt daily for several years will die of cobalt toxicity. This is equivalent to a daily consumption of $13.3-47 \mathrm{~g}$ and $10-$ $35 \mathrm{~g}$ of Tilapia guineensis and Sarotherodon melanotheron respectively from Bodo River. These weights are less than the average weight of a single table size of any of the two species. Therefore, people are likely to be in danger of cobalt toxicity through the consumption of Tilapia guineensis and Sarotherodon melanotheron from Bodo River.

Zinc: Zinc is essential for growth and development, maintaining appetite, healing of wound and an important component of DNA (EMEA, 2007). In the US $15 \mathrm{mg} /$ day is recommended for adult men and $12 \mathrm{mg} /$ day for adult women but with an additional $3 \mathrm{mg} /$ day during pregnancy and $7 \mathrm{mg} /$ day during lactation (EMEA, 2007). However, a long term oral intake of zinc of $18-25 \mathrm{mg} /$ day interferes with the absorption of copper. WHO has recommended a total daily intake of $0.3-1.0 \mathrm{mg} / \mathrm{kg}$ body weight per day (EMEA, 2007). This means that to stay away from the toxic effects of zinc an adult of $60 \mathrm{~kg}$ will ensure that the range of zinc consumed per day is between 18$60 \mathrm{mg}$. The amount of zinc found in $1 \mathrm{~kg}$ of Tilapia guineensis and Sarotherodon melanotheron in Bodo River is $74.5 \mathrm{mg}$ and $71.2 \mathrm{mg}$ respectively. Thus, the above recommended range of zinc for persons of $60 \mathrm{~kg}$ is equivalent to $241-805 \mathrm{~g}$ and $252-843 \mathrm{~g}$ per day of Tilapia guineensis and Sarotherodon melanotheron respectively from Bodo River. This means that the maximum number of table size fish for any of the two fish species to be consumed per day is about twelve. Therefore, moderation in the amount of Tilapia guineensis and Sarotherodon melanotheron from Bodo River that are consumed per day is required to avoid zinc toxicity.

Conclusion: Although some unsafe amount of chromium for humans has been established, the lowest amount of these fish species that if consumed can lead to chromium toxicity is not clearly understood. However, $10-20 \mathrm{mg} / \mathrm{kg}$ of chromium per body weight per day has been reported to be toxic. The dangers of nickel and cobalt toxicity through the consumption of Tilapia guineensis and Sarotherodon melanotheron found in Bodo River are highlighted. Toxicity of zinc through the consumption these two fish species among others also depend on the body weight and the amount of these fish species consumed per day. The need for Food Agencies in Nigeria to certify the safety of fishes from our own rivers and not just those coming from overseas before they are sold to the public for consumption is hereby highlighted. 


\section{REFERENCES:}

Committee on Medical Aspects of Food Policy (1991). Dietary reference values for food energy and nutrients for the United Kingdom. Department of Health Report 41:181-182.

European Medicines Agency (2007). Preauthorization Evaluation of Medicines for Human Use, p.1-32.

Environmental Protection Agency (1984). Health assessment document for chromium. Research Triangle Park, NC. Final Report No. EPA600/8-83-014F) p.114.

Kaufaman, DB (1970). Acute potassium dichromate poisoning treated by peritoneal dialysis. Am. J.Dis. Child 119: 374-376.

Langard, S. (1983). The carcinogenicity of chromium compounds in man and animals. Boca Raton, FL, CRC Press: p.13-30

Langard, S; Norseth, T (1986). Handbook on the toxicology of metals, $2^{\text {nd }}$ edition, vol. 11. Amsterdam, Elsevier/North-Holland Biomedical Press: p.185-210.

FAO/WHO (2010). Summary and conclusions of the seventy-second meeting of the Joint FAO/WHO Expert Committee on Food Additives, Rome, 16-25 February. Rome, Food and Agriculture Organization of the United Nations; Geneva, World Health Organization (JECFA/72/SC) p.1-15.

Kpobari, WN; Mathew, O; Eka, BE (2013). Heavy metal concentrations in four selected seafood from crude oil polluted waters of Ogoniland, Rivers State, Nigeria. Archives of Appl. Sci. Res. 5 (4):97-104.

Jumbo, A.; Wegwu, MO; Belonwu, DC; Okerenta, BM (2015). Assessment of heavy metals concentration of selected fin and shell fish from Ogoniland. J. Environ. Earth Sci. 5 (18): 15-19.

Ogwuegbu, MO; Ijioma, MA (2003). Effects of Certain Heavy Metals on the Population Due To Mineral Exploitation. In: International Conference on Scientific and Environmental Issues In The
Population, Environment and Sustainable Development in Nigeria, University of Ado Ekiti, Ekiti State, Nigerian p.8-10.

Osman, A; Wuertz, S; Mekkawy, I; Exner, H; Kirschbaum, F (2007). J. Environ. Toxic. 22 (4): 375389.

Racchelle, B (2008). Department of Medicine, University of Montreal. Lung cancer risk associated with occupational exposure to nickel, chromium (VI) and cadmium in two population-based studies in Montreal. p. 10-15.

Rasheed, MN (2001). Egypt monitoring of environmental heavy metals in fish from Nasser Lake. Environ. Int., 27: 27-33.

Ravera, RC; Beone, GM; Dantas, M; Lodigiani, P (2003). Trace Element Concentrations in Freshwater Mussels and Macrophytes as Related to Those in Their Environment, J. Lim., 62 (1): 61-70.

Scientific Committee on Food (1993). Nutrient and Energy intakes for the European Community. Reports of the Scientific Committee on Food, thirty first series, EC, Luxembourg, p.1-25.

Sivaperumal, P; Sankar, TV; Nair, PGV (2007). Heavy metal concentrations in fish, shellfish and fish product from internal markets of India vis-à-vis international standards. Food Chem. 102 (61): 612-620.

Svobodova, Z; Celechovska, O; Kolara, J; Randak, T; Zlabek, V (2004). "Assessment of Metal Contamination in the Upper Reaches of the Ticha Orlice River," Czech J. Anim. Sci., 49 (4): 458-641.

WHO (1996). Trace Elements in human nutrition and health. Geneva, p.1-15.

WHO (2000). Chromium. Air Quality Guidelines for Europe, 2nd ed. Copenhagen, Denmark: WHO Regional Office for Europe, Chapter 6, p.1-14.

WHO (2006). Cobalt and inorganic cobalt compounds. Concise International Chemical Assessment Document, 69p.1-93. 